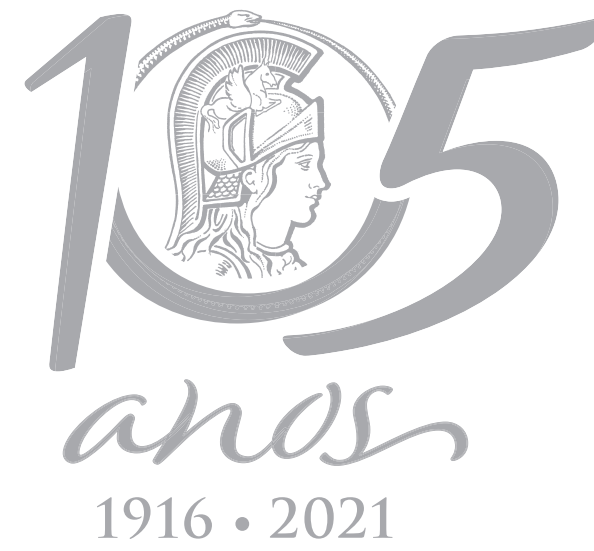

$1916 \cdot 2021$

\title{
Structure of the ichthyoplankton community in a Neotropical floodplain lake affected by environmental degradation
}

\author{
LUCAS S. DE OLIVEIRA, RUINERIS A. CAJADO, LUAN R.B. DOS SANTOS \& DIEGO M. \\ ZACARDI
}

\begin{abstract}
Many Amazonian fish' reproduction is associated to seasonality and to the conditions of habitat integrity. In a Neotropical floodplain lake of the Amazon region, the temporal structure of ichthyoplankton was investigated and the hypothesis that the density of fish eggs and larvae and the diversity of species vary between two areas with different levels of environmental changes occurred was tested. The sampling occurred monthly between September 2017 and August 2018. Six sampling stations were used, distributed in locations close to and far from the altered area. 195 eggs and 1,785 larvae from nine orders and 27 species were captured. The eggs were from nonmigratory fish species and occurred during two moments. The larvae presented different abundance peaks during the sample months and all the initial stages of development occurred. Clupeiformes was the most abundant and Characiformes the species richest. The density of the ichthyoplankton and the diversity of species presented temporal variation. However, only the larval density varied between the areas of the lake. The Lake Juá is a spawning area for resident fish and is a nursery and growth area for larvae of species with different ecological categories and socioeconomic importance during different periods of the year.
\end{abstract}

Key words: Amazon, fish eggs and larvae, impacted area, Neotropical fishes, spawning, nursery.

\section{INTRODUCTION}

The environmental conditions of lakes adjacent to the numerous Amazonian rivers are associated with the seasonal dynamics of the flood pulse that generates temporary changes in their morphometry and in their existing habitats (Melack et al. 2009, Junk et al. 2012, Brito et al. 2017). Variations in water level allow the maintenance of natural patterns of longitudinal and lateral connectivity of water bodies and contribute to the dispersion and viability of fish populations (Osorio et al. 2011, Ortega et al. 2015).
In recent years, these aquatic environments have undergone several alterations of anthropogenic origin, causing severe impacts and interference in the relations of the fauna with the environment (Castello et al. 2013, Arantes et al. 2018, 2019). Thus, they compromise the provision of ecosystem services and generate socioeconomic losses to traditional populations.

The Amazonian ichthyofauna is one of the richest and most diverse biological communities in number of species (Reis et al. 2016, Dagosta \& Pinna 2019). This diversity is associated with the large number of aquatic ecosystems, the extent of the basin and/or linked to ecological 
factors such as habitat complexity, biotopes, physicochemical parameters, among other factors. The existence of these conditions allows them to play a relevant role and directly influence the life history of fish (Leal et al. 2018, Oberdorff et al. 2019, Oliveira et al. 2020a).

Understanding the patterns and variations in the distribution and composition of egg and larvae of fish assemblage leads to insights on aspects that regulate the biological recruitment of species and serves as an effective method in the determination and delimitation of spawning and growth times and areas (Silva et al. 2012, Cajado et al. 2020a). However, studies of this nature in oligotrophic water environments in the Amazon are scarce and are limited to the work of Lima \& Araujo-Lima (2004), Zacardi \& Ponte (2016) and Cajado et al. (2020a).

In this context, this study aims to evaluate the variation of the structure and diversity of fish eggs and larvae in a Neotropical floodplain lake in the Amazon region through analysis of composition, abundance and occurrence of development stages. Due to the several anthropic processes that occurred in the studied area and the existence of a more preserved and a more altered area, the hypothesis that the density of the ichthyoplankton and the diversity of species differ between the two areas over the sampling months was tested.

\section{MATERIALS AND METHODS}

\section{Study area}

Lake Juá is located around an Environmental Protection Area (APA of Juá) on the right bank of the Tapajós River $\left(2^{\circ} 25^{\prime} 55^{\prime \prime} \mathrm{S}\right.$ and $54^{\circ} 46^{\prime} 36^{\prime \prime}$ W) near the confluence with the Amazon River, Lower Amazon, Pará, Brazil (Fig. 1). The lake presents seasonal morphological variation due to: the annual flood pulse of the region, the local rainfall peak and the confluence flow of many headwaters and igarapés (streams) in its surroundings. This water body is connected to the Tapajós River through a short winding and perennial channel.
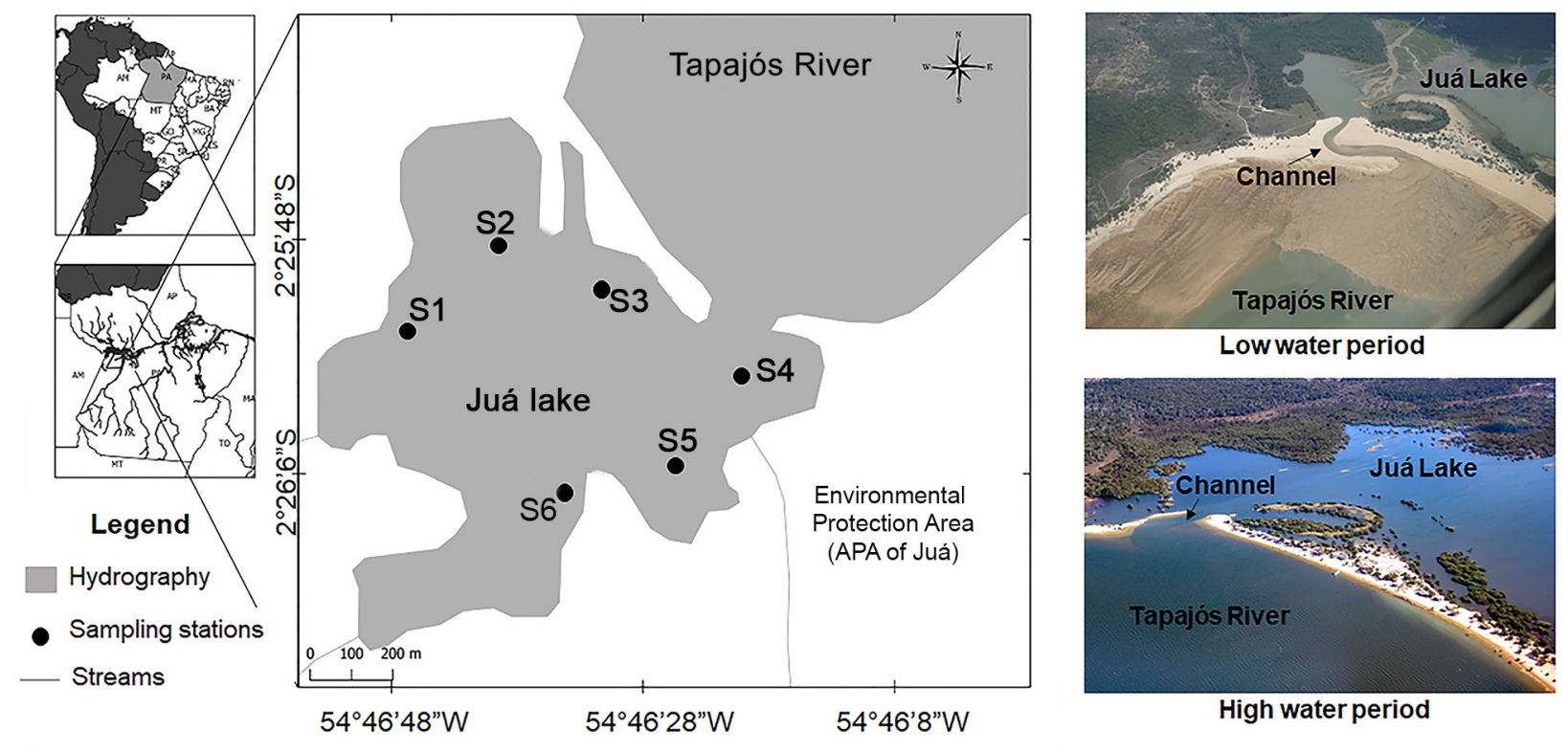

Figure 1. Study area with emphasis on Lake Juá located at the mouth of the Tapajós River and the distribution of sampling points. Photos of Manuel Dutra (low water) and Celso Lobo (high water). 
This lake environment is widely used by several fishermen and local residents who survive directly or indirectly from fishing (Rabelo et al. 2017, Corrêa et al. 2018, Serrão et al. 2019). However, Lake Juá is suffering from the effects of anthropogenic intervention that have caused fires, deforestation, silting and erosion of its marginal areas to give way to irregular occupation that houses hundreds of families and a large housing development. These activities have caused several conflicts between residents, fishermen, entrepreneurs and public agencies (Corrêa et al. 2018, Nascimento \& Santos 2019, Cardoso et al. 2021).

The local climate is humid tropical, with an average annual temperature of $27.7^{\circ} \mathrm{C}$ and little variability in humidity and air temperature. The average rainfall is $2,096 \mathrm{~mm}$, with the highest concentrations between December and June (rainy season) and the lowest between July and November (dry season) (Costa et al. 2013).

\section{Sampling}

The samples were collected monthly between September 2017 and August 2018 in daytime and nighttime samplings, totaling 144 samples. The license for the collection of biological material was granted by Sistema de Autorização e Informação em Biodiversidade (SISBIO) of Instituto Chico Mendes de Conservação da Biodiversidade (ICMBio), authorization number 72,330, issued based on Normative Instruction no. 154/2007 of Instituto Brasileiro do Meio Ambiente e dos Recursos Naturais Renováveis (IBAMA).

The samplings occurred in six stations properly georeferenced and spatially divided into two areas: area 1- "more conserved" (S1, S2 and S3) and area 2- "more altered" (S4, S5 and S6). The area considered most conserved on the lake has little landscape alteration in its riparian forest and is widely used as a fishing spot. The area considered most altered, on the other hand, has a large surrounding area deforested, high rates of sedimentation, allochthonous inorganic material from areas deforested by the developments adjacent to the lake, in addition to undergoing an intense silting process.

The ichthyoplankton was captured, on board a local vessel, by horizontal trawling on the subsurface of the water column using plankton net (300 $\mu \mathrm{m}$ mesh) with a coupled flowmeter to obtain the volume of filtered water. The samples were submitted to Eugenol solution (50 mg/L), fixed in $10 \%$ formalin solution buffered with calcium carbonate and packed in polyethylene bottles $(500 \mathrm{~mL})$. The fluviometric level data were provided by the Capitania Fluvial da Marinha do Brasil in Santarém, state of Pará, Diretoria de Hidrografia e Navegação.

\section{Sample processing}

The samples were sorted by separating the larvae from the suspended material and from the total plankton using a stereoscopic microscope. Subsequently, the eggs were quantified and classified according to the reproductive strategy of the species (migratory and non-migratory) and the stages of embryonic development were determined. The larvae were also quantified and identified at the lowest possible taxonomic level by specialized bibliographies, and they were classified as the larval development phase. These classifications were based on Nakatani et al. (2001) and Orsi et al. (2016).

The taxonomic framework was based on Betancur-R et al. (2017) and the reproductive strategy (migratory and non-migratory) of the species based on the information of adult individuals (Barthem \& Fabré 2004, GranadoLorencio et al. 2005, Goulding et al. 2019). Specimens were deposited in the Laboratório de Ecologia do Ictioplâncton e Pesca em Águas 
Interiores at the Universidade Federal do Oeste do Pará to constitute a reference collection.

\section{Data analysis}

The abundance was standardized for ichthyoplankton density by $10 \mathrm{~m}^{-3}$ of filtered water according to Nakatani et al. (2001). The density data matrix of fish eggs and larvae did not meet the assumptions of normality (ShapiroWilk test) and homoscedasticity (Levene test) and therefore only nonparametric analyses were used.

To verify possible significant differences in ichthyoplankton density variation between sampling months, the Kruskal-Wallis test was applied. The Bonferroni post-hoc correction test was used to adjust the alpha values to determine statistical significance. Larval density and abundance of development stages were considered as predictor variables and sampling months as response variable. An analysis of similarities (ANOSIM) was performed to test whether species composition and larval stages significantly differed between the sampling months. When different, similarity percentages (SIMPER) were performed to identify the species responsible for the variation. Before the analyses, the data were transformed into log $(x+1)$ and the similarity matrices based on the Bray-Curtis distance (Clarke 1993).

A nested two-way permutational multivariate analysis of variance (two-way PERMANOVA nested design) was performed to verify differences in the density of eggs and fish larvae and the diversity of species as a function of the sampled areas (conserved and altered) and the months of sampling. PERMANOVA was performed based on the Hellinger distance matrix with 999 permutations (Anderson 2001). Species diversity was based on the ShannonWiener index (Magurran 2013). The statistical tests were performed in the software R Studio version 4.0.1, Vegan package (Oksanen et al. 2019) with the significance level of $p<0.05$.

\section{RESULTS}

A total of 195 eggs and 1,785 fish larvae were collected. All eggs belonged to non-migratory species and were obtained only in two months of sampling. The larvae presented heterogeneous distribution but were recorded in all sampling stations and were taxonomically grouped into nine orders, 18 families and 27 species (Table I). Of all captured species, 48.15\% ( $n=13)$ have economic importance for the Amazon region. Most are sedentary and do not perform reproductive migrations (63\%; $n=$ 17). Clupeiformes (five species) was the most abundant order (54\%), followed by Gobiiformes (one species) (23\%) and Characiformes (13 species) (17\%), which together made up more than $90 \%$ of the total captured larvae, making these groups the most representative in the study area (Fig. 2).

The eggs were obtained only in two sampling months: April, which is characterized as the end of the Tapajós River flood period, with the capture of Loricariichthys acutus carrying eggs in the final phase of development; and December, with the contribution of pelagic eggs of non-guarding species (Fig. 3). The temporal distribution of egg density varied significantly over the sampling months $(\mathrm{KW}-\mathrm{H}=27.718 ; \mathrm{p}=$ 0.0036), April differed from the other months (Dunn's test; $p<0.05$ ).

Larval density also varied significantly over the months $(\mathrm{KW}-\mathrm{H}=36.647 ; \mathrm{p}=0.0001)$, with a clear seasonality pattern. This difference is the result of the variations observed between October and April (Dunn's Test; $p=0.0014$ ), October and November (Dunn's test; $p=0.0004$ ), 
Table I. Taxonomic composition, total abundance and monthly variation of the density of ichthyoplankton collected in Lake Juá, during samplings from September 2017 to August 2018, at the mouth of the Tapajós River, state of Pará, Brazil. El: economic importance. ( $\bullet$ Marketed in regional marts and fairs. ( () ) Ecological importance in the ecosystem. TN: total number. RS: reproductive strategy. M: migratory species. NM: non-migratory species.

*Yolk-sac stage individual.

\begin{tabular}{|c|c|c|c|c|c|c|c|c|c|c|c|c|c|c|c|}
\hline $\begin{array}{l}\text { ORDER/ FAMILYI } \\
\text { SPECIES }\end{array}$ & TN & Jan & Feb & Mar & Apr & May & Jun & Jul & Aug & Sep & Oct & Nov & Dec & EI & RS \\
\hline CHARACIFORMES & $153^{*}$ & 0.16 & - & 0.03 & 0.02 & - & - & - & - & - & - & - & 21.61 & & \\
\hline \multicolumn{16}{|l|}{ Anostomidae } \\
\hline $\begin{array}{l}\text { Rhytiodus microlepis } \\
\text { Kner, } 1858\end{array}$ & 2 & - & - & - & - & - & - & - & - & - & - & - & 0.23 & 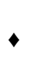 & M \\
\hline Characidae & 3 & 0.03 & - & - & - & - & - & - & - & - & - & 0.03 & 0.02 & & \\
\hline $\begin{array}{l}\text { Hyphessobrycon cf. } \\
\text { pulchripinnis Ahl, } 1937\end{array}$ & 2 & - & 0.01 & - & - & - & - & - & - & - & - & - & 0.08 & $\diamond$ & NM \\
\hline Moenkhausia sp. & 5 & - & 0.02 & - & - & - & - & - & - & - & - & - & 0.38 & $\diamond$ & NM \\
\hline \multicolumn{16}{|l|}{ Curimatidae } \\
\hline $\begin{array}{c}\text { Psectrogaster } \\
\text { amazonica Eigenmann } \\
\text { \& Eigenmann, } 1889\end{array}$ & 51 & 0.18 & 0.19 & - & - & - & - & - & - & - & - & 0.09 & 4.77 & - & M \\
\hline \multicolumn{16}{|l|}{ Erythrinidae } \\
\hline $\begin{array}{l}\text { Hoplias malabaricus } \\
\quad \text { (Bloch, 1794) }\end{array}$ & 4 & - & - & - & - & - & - & - & - & - & - & - & 0.32 & - & NM \\
\hline \multicolumn{16}{|l|}{ Hemiodontidae } \\
\hline $\begin{array}{l}\text { Anodus elongatus } \\
\text { Agassiz, } 1829\end{array}$ & 1 & - & 0.01 & - & - & - & - & - & - & - & - & - & - & $\bullet$ & M \\
\hline $\begin{array}{c}\text { Hemiodus cf. } \\
\text { immaculatus Kner, } 1858\end{array}$ & 22 & 0.31 & 0.03 & - & - & - & - & - & - & 0.17 & - & - & 0.28 & 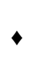 & M \\
\hline $\begin{array}{c}\text { Hemiodus cf. } \\
\text { unimaculatus (Bloch, } \\
\text { 1794) }\end{array}$ & 49 & 0.19 & - & - & 0.02 & - & - & 0.48 & 3.23 & 0.32 & - & 0.06 & 0.31 & - & M \\
\hline $\begin{array}{l}\text { Hemiodus cf. microlepis } \\
\text { Kner, } 1858\end{array}$ & 2 & - & - & - & - & - & - & - & - & - & - & - & 0.23 & - & M \\
\hline Hemiodus sp. & 3 & 0.02 & 0.01 & - & 0.02 & - & - & - & - & - & - & - & - & 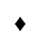 & M \\
\hline \multicolumn{16}{|l|}{ Iguanodectidae } \\
\hline $\begin{array}{l}\text { Iguanodectes spilurus } \\
\text { (Gunther, 1864) }\end{array}$ & 1 & - & - & - & - & - & - & - & - & - & - & - & 0.15 & $\diamond$ & NM \\
\hline Serrasalmidae & - & & & & & & & & & & & & & & \\
\hline
\end{tabular}


Table I. Continuation.

\begin{tabular}{|c|c|c|c|c|c|c|c|c|c|c|c|c|c|c|c|}
\hline $\begin{array}{l}\text { Mylossoma aureum } \\
\text { (Spix \& Agassiz, 1829) }\end{array}$ & 2 & - & - & - & - & - & - & 0.13 & - & - & - & - & - & $\bullet$ & M \\
\hline $\begin{array}{c}\text { Serrasalmus sp. (Cuvier, } \\
\text { 1818) }\end{array}$ & 3 & 0.02 & - & 0.03 & 0.02 & - & - & - & - & - & - & - & - & $\bullet$ & NM \\
\hline CICHLIFORMES & - & & & & & & & & & & & & & & - \\
\hline Cichlidae & 1 & - & - & - & - & - & - & - & - & - & 1.72 & - & - & - & \\
\hline Crenicichla sp. & 1 & - & - & - & - & - & - & - & - & - & - & - & 0.08 & $\diamond$ & NM \\
\hline CLUPEIFORMES & 67 & - & - & - & - & - & - & - & - & 0.59 & - & - & 6.00 & & \\
\hline Engraulidae & 497 & 0.43 & 1.16 & 1.51 & 0.24 & 4.30 & 1.81 & 3.64 & 2.59 & 0.84 & 1.72 & 0.15 & 16.38 & $\diamond$ & \\
\hline $\begin{array}{l}\text { Anchoviella guianensis } \\
\text { (Eigenmann, 1912) }\end{array}$ & 15 & - & 0.12 & 0.03 & - & - & - & - & - & - & 13.23 & - & 0.62 & $\diamond$ & NM \\
\hline $\begin{array}{c}\text { Anchoviella jamesi } \\
\text { (Jordan \& Seale, 1926) }\end{array}$ & 263 & 31.69 & 0.48 & 0.72 & 0.01 & - & 0.16 & - & - & 0.81 & 188.61 & - & 8.07 & $\diamond$ & NM \\
\hline $\begin{array}{c}\text { Anchoviella } \\
\text { juruansanga Loeb, } 2012\end{array}$ & 113 & - & 1.23 & 0.69 & 0.07 & 0.38 & 0.31 & 0.82 & 0.24 & 0.17 & - & 0.22 & - & $\diamond$ & NM \\
\hline Pristigasteridae & - & & & & & & & & & & & & & & \\
\hline $\begin{array}{l}\text { Pellona flavipinnis } \\
\text { (Valenciennes, 1837) }\end{array}$ & 4 & - & - & - & - & - & - & - & - & 0.20 & - & - & - & $\bullet$ & M \\
\hline GOBIIFORMES & - & & & & & & & & & & & & & & \\
\hline Eleotridae & - & & & & & & & & & & & & & & \\
\hline $\begin{array}{c}\text { Microphilypnus } \\
\text { tapajosensis Caires, } \\
2013\end{array}$ & 414 & 4.35 & 1.45 & 0.65 & 0.36 & 1.54 & 0.92 & 1.07 & 1.01 & 35.1 & - & 0.16 & 5.40 & $\diamond$ & NM \\
\hline GYMNOTIFORMES & - & & & & & & & & & & & & & & \\
\hline Sternopygidae & - & & & & & & & & & & & & & - & \\
\hline $\begin{array}{l}\text { Sternopygus cf. } \\
\text { macrurus (Bloch \& } \\
\text { Schneider, 1801) }\end{array}$ & 2 & - & 0.02 & - & - & - & - & - & - & - & - & - & - & $\diamond$ & NM \\
\hline Eigenmannia sp. & 1 & - & - & - & 0.04 & - & - & - & - & - & - & - & - & $\diamond$ & NM \\
\hline PERCIFORMES & - & & & & & & & & & & & & & & \\
\hline Sciaenidae & - & & & & & & & & & & & & & & \\
\hline
\end{tabular}


Table I. Continuation.

\begin{tabular}{|c|c|c|c|c|c|c|c|c|c|c|c|c|c|c|c|}
\hline $\begin{array}{l}\text { Plagioscion } \\
\text { squamosissimus } \\
\text { (Heckel, 1840) }\end{array}$ & 2 & - & - & - & - & 0.11 & - & - & - & - & - & - & - & $\bullet$ & NM \\
\hline PLEURONECTIFORMES & - & & & & & & & & & & & & & & \\
\hline Achiridae & & & & & & & & & & & & & & & \\
\hline $\begin{array}{l}\text { Hypoclinemus mentalis } \\
\text { (Günther, 1862) }\end{array}$ & 43 & - & - & - & - & 1.33 & 0.47 & 0.40 & 0.21 & 0.17 & - & - & - & $\diamond$ & NM \\
\hline SILURIFORMES & 1 & - & - & 0.02 & - & - & - & - & - & - & - & - & - & & \\
\hline Auchenipteridae & - & & & & & & & & & & & & & & \\
\hline $\begin{array}{c}\text { Trachelyopterus cf. } \\
\text { coriaceus Valenciennes, } \\
1840\end{array}$ & 2 & - & 0.05 & - & - & - & - & - & - & - & - & - & - & $\diamond$ & NM \\
\hline Doradidae & 5 & - & 0.09 & - & 0.02 & - & - & - & - & - & - & - & - & & \\
\hline Trichomycteridae & - & & & & & & & & & & & & & & \\
\hline Paracanthopoma sp. & 2 & - & - & - & 0.02 & - & 0.04 & - & - & - & - & - & - & $\diamond$ & NM \\
\hline TETRAODONTIFORMES & - & & & & & & & & & & & & & & \\
\hline Tetraodontidae & - & & & & & & & & & & & & & & \\
\hline $\begin{array}{c}\text { Colomesus asellus } \\
\text { (Müller \& Troschel, } \\
\text { 1849) }\end{array}$ & 6 & - & 0.03 & - & - & 0.42 & 0.04 & - & - & - & - & - & - & $\diamond$ & NM \\
\hline Unidentified larvae & 41 & 0.44 & 0.13 & 0.02 & - & 0.55 & 0.04 & 0.61 & 1.16 & - & 1.95 & - & - & & \\
\hline Total (larvae) & 1.785 & 263 & 243 & 139 & 57 & 110 & 65 & 74 & 52 & 68 & 81 & 18 & 615 & & \\
\hline $\begin{array}{c}\text { Eggs of non-migratory } \\
\text { species (non-guarding } \\
\text { species) }\end{array}$ & 38 & - & - & - & - & - & - & - & - & - & - & - & 3.11 & & NM \\
\hline $\begin{array}{c}\text { Eggs of non-migratory } \\
\text { species (guarding } \\
\text { species) }\end{array}$ & 157 & - & - & - & 3.10 & - & - & - & - & - & - & - & - & & NM \\
\hline Total (eggs) & 195 & - & - & - & 157 & - & - & - & - & - & - & - & 38 & & \\
\hline
\end{tabular}


November and January (Dunn's Test; $p=0.0094$ ) and November and May (Dunn's Test; $p=0.0186$ ).

The species composition also differed between months (ANOSIM; Global R= 0.468; $p<0.0001)$. A high dissimilarity was recorded (SIMPER; > 60\%) with high contribution of Pleuronectiformes (Hypoclinemus mentalis) during May, from Gobiiformes (Microphilypnus tapajosensis) in September, individuals of the order Clupeiformes (species of the genus Anchoviella) in October and by the Characiformes (Hemiodus immaculatus,
Hemiodus unimaculatus and Psectrogaster amazonica) during December (Fig. 3).

Through PERMANOVA it was possible to verify significant differences in spatial, temporal effects and the interaction of the two factors only for the larval community (Table II), indicating a variation of fish larvae between the two areas studied between the sampling months (Fig. 4b). The highest egg densities in the most conserved region of the lake (Fig. $4 \mathrm{a}$ ) indicate that this site is a spawning area for non-migratory species. The diversity of species did not vary significantly

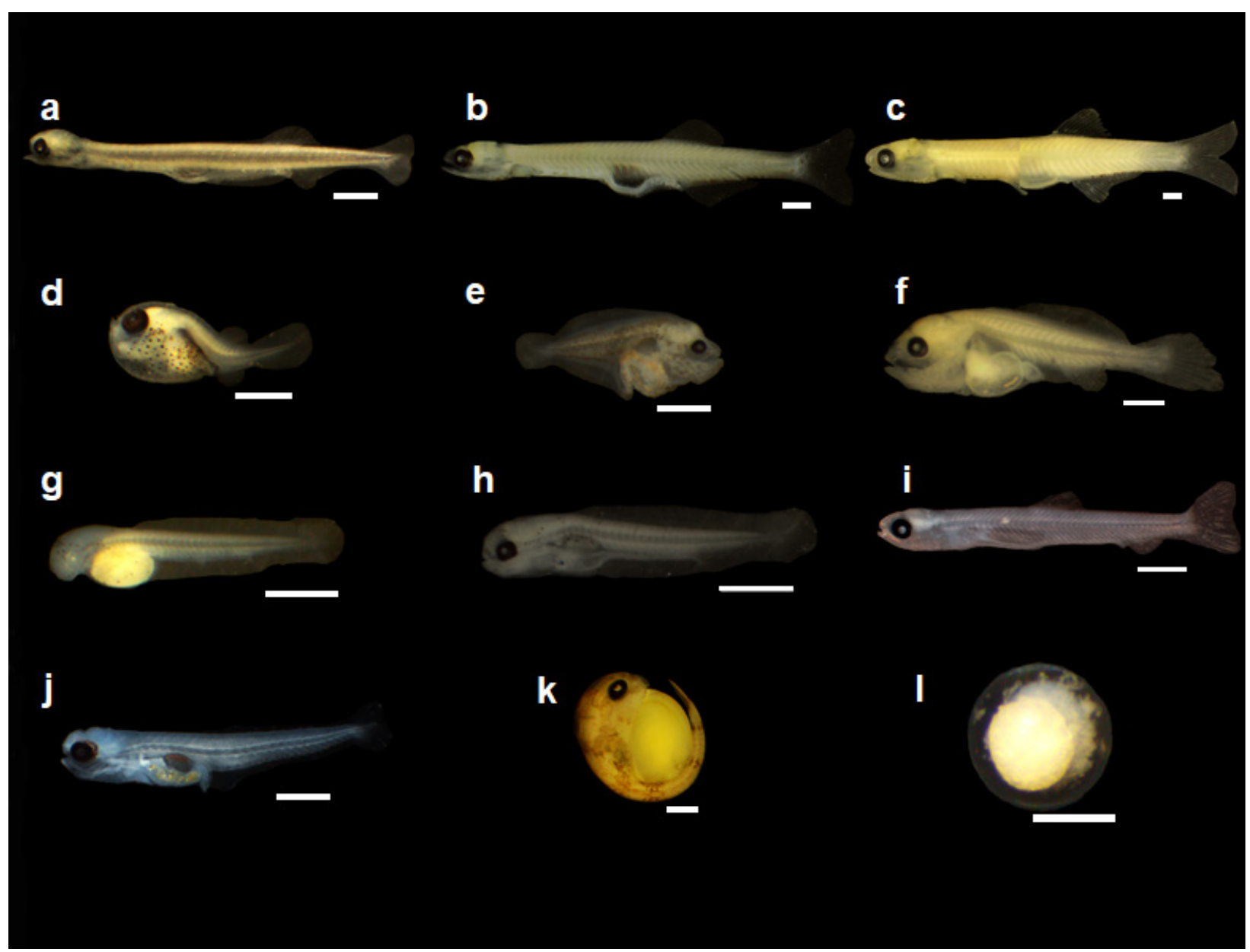

Figure 2. Images of some ichthyoplankton organisms collected during samplings from September 2017 to August 2018 at Lake Juá, at the mouth of the Tapajós River, state of Pará, Brazil. a) Engraulidae; b) Anchoviella juruassanga; c) Anchoviella jamesi; d) Colomesus asellus; e) Hypoclinemus mentalis; f) Plagioscion squamosissimus; g) Characiformes yolk-sac stage; h) Psectrogaster amazonica; i) Hemiodus immaculatus; j) Microphilypnus tapajosensis; k) egg with visualization of the embryo of Loricariichthys acutus in the final stage (guarding species) and l) pelagic egg in the initial cleavage of non-guarding specie. Bars = $1 \mathrm{~mm}$. 
between the two areas studied, presenting only temporal variation (Table II) (Fig. 4C).

Only eggs in two stages of embryonic development were captured, with significant difference of density between the sampling month for those in initial cleavage (KW-H= 10.50; $p=0.005$ ). Eggs in the final embryo stage corresponded to $80.5 \%$ of the total catch, while those in the initial cleavage represented only 19.5\% (Fig. 5a). All larval stages of development were captured and significant variations in their abundances were verified throughout the sampling months (ANOSIM; Global R=0.303; $\mathrm{p}=$ 0.001). Most larvae were in preflexion stage (49\%) and the lowest captures were from individuals in the yolk-sac stage (9.27\%) (Fig. 5b).

\section{DISCUSSION}

The ichthyoplankton community of the lake was composed mostly of individuals of non-migratory species and presented variation in composition and density over the sampling months. The absence of eggs from species that perform reproductive migration was already expected, since the reproduction of this group is associated with nutrient-rich rivers (e.g., Amazon/Solimões River) that favor the development of pelagic and semi-dense eggs through the dynamics of its currents (Lopes \& Zaniboni-Filho 2019, Zacardi et al. 2020a, Cajado et al. 2020b). In Neotropical lentic environments, the reproduction of ichthyofauna is more favorable for species that have parental care strategies throughout their life histories (Nakatani et al. 2001, Orsi 2010, Garcia et al. 2018).

The higher numerical capture of Clupeiformes may be related to the ecological and biological aspects of this group. Clupeiformes species present great trophic and reproductive flexibility and may complete their life cycles in several environments (Bloom \& Egan 2018, Egan et al. 2018). However, following the composition patterns of Amazonian fish described by Dagosta

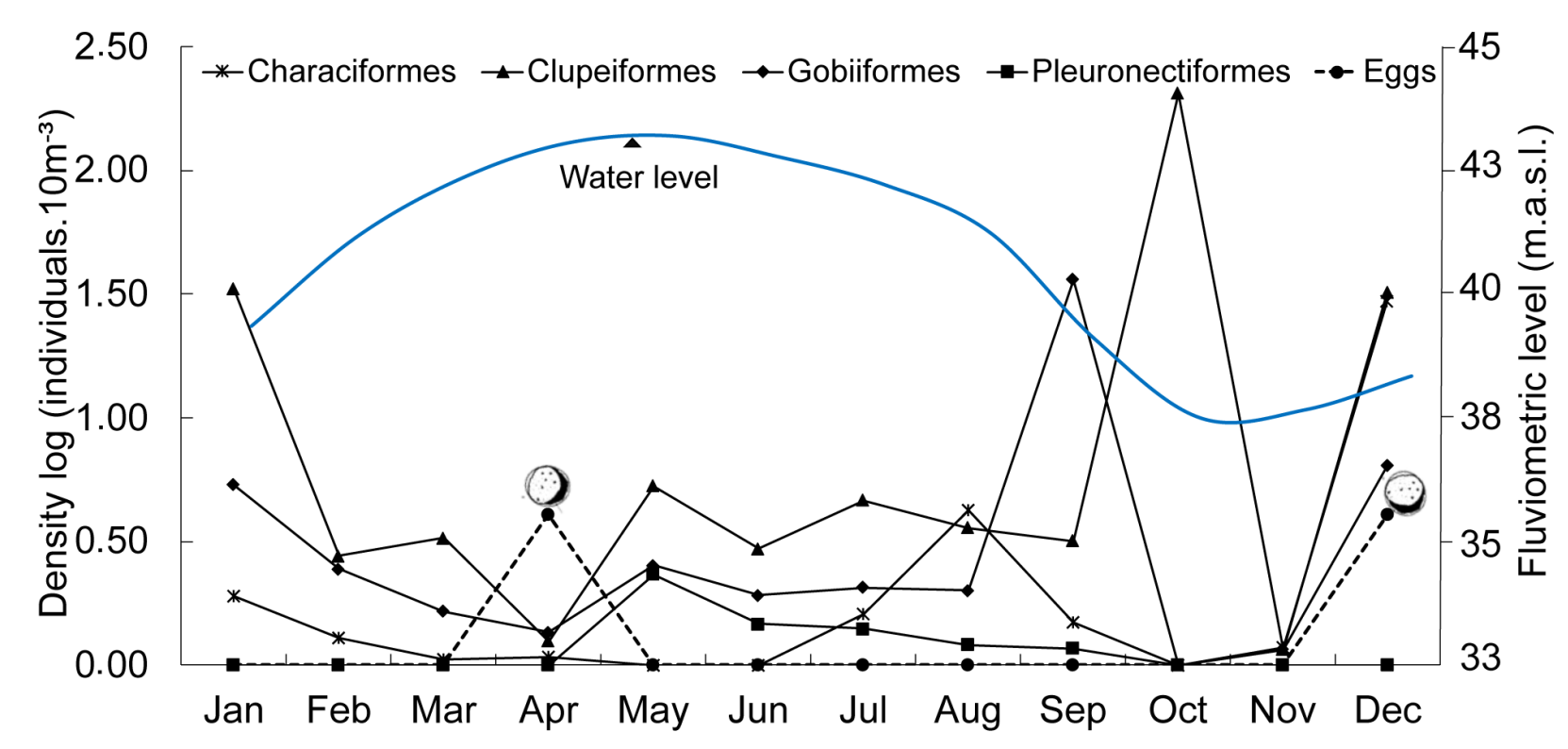

Figure 3. Variation of the density (log transformed) of orders with relative abundance above $2 \%$ over the sampling period in Lake Juá and variation of the water level of the Tapajós River, state of Pará, Brazil. m.a.s.l = meters above sea level. 
\& Pinna (2019), the order Characiformes was more diverse and represented mostly by small and medium-sized species.

Among the Clupeiformes, the Engraulidae was the most abundant along with the species of the genus Anchoviella. This group acquired several specific (morphological and ecological) adaptive advantages along its radiation in the South American basins (Nynatten et al. 2015, Bloom \& Lovejoy 2017). This allowed them to use new niches and succeed in colonizing the aquatic freshwater of the Amazon. Another abundant order was the Gobiiformes represented solely by Microphilypnus tapajosensis. It is considered a forage species, small-sized and without economic importance, but of great importance for the aquatic trophic chain (Caires 2013, Oliveira et al. 2020b). This information allows us to highlight the relevance of Lake Juá as a nursery area for these two groups.

Lake Juá is widely used for the capture of several fish species, especially the "jaraquis" Semaprochilodus insignis (Jardine 1841) and Semaprochilodus taeniurus (Valenciennes 1821), which constitute an important food item of the
Amazon population (Corrêa et al. 2018), but larvae of these species were not recorded. According to Zacardi et al. (2017b) the Semaprochilodus use the lowland areas along the trough of whitewater rivers as breeding sites and nurseries. However, larvae from other groups with relative socioeconomic importance were found in the lake (species of the genus Hemiodus "charutinhos", Psectrogaster amazonica "branquinhas", Plagioscion squamosissimus "pescada-branca" and Pellona castelnaeana and P. flavipinnis "apapás"), as well as by adult individuals (Corrêa et al. 2018). This condition demonstrates the ability of this lake environment to assist in the maintenance of fishery stocks.

In the Amazon region, many fish species usually spawn during the first months of the year, due to heavy rains and increased water level in the main rivers (Ponte et al. 2017, Zacardi et al. 2017a, b). However, the reproduction of other species can occur at different times (Chaves et al. 2019, Ponte et al. 2019, Serrão et al. 2019), as observed in this study. For example, Clupeiformes larvae, mainly from Engraulidae, which presented their highest abundances

Table II. Summary of the two-way PERMANOVA on the spatial and temporal effects on the density of fish eggs and larvae and on the diversity of species in Lake Juá at the mouth of the Tapajós River, state of Pará, Brazil. Values in bold represent a significant difference. df: degree of freedom. Pseudo-F: pseudo-F statistics. $R^{2}$ : $R$ squared.

\begin{tabular}{|c|c|c|c|c|c|}
\hline Community & Variables & df & Pseudo-F & $\mathbf{R}^{\mathbf{2}}$ & $\mathbf{p}$-value \\
\hline \multirow{3}{*}{ Eggs } & Temporal & 11 & 1.093 & 0.165 & $\mathbf{0 . 0 2 7}$ \\
\cline { 2 - 6 } & Spatial & 1 & 2.136 & 0.029 & 0.138 \\
\cline { 2 - 6 } & Temporal vs Spatial & 11 & 0.977 & 0.147 & 0.532 \\
\hline \multirow{3}{*}{ Larvae } & Temporal & 11 & 11.896 & 0.427 & $\mathbf{0 . 0 0 1}$ \\
\cline { 2 - 6 } & Spatial & 1 & 7.959 & 0.026 & $\mathbf{0 . 0 0 2}$ \\
\cline { 2 - 6 } & Temporal vs Spatial & 11 & 10.874 & 0.390 & $\mathbf{0 . 0 0 1}$ \\
\hline \multirow{3}{*}{ Diversity } & Temporal & 11 & 2.499 & 0.312 & $\mathbf{0 . 0 1 9}$ \\
\cline { 2 - 6 } & Spatial & 1 & 2.304 & 0.026 & 0.151 \\
\cline { 2 - 6 } & Temporal vs Spatial & 11 & 0.940 & 0.117 & 0.518 \\
\hline
\end{tabular}


during October - drought and lower water level, confirming the reproduction pattern of the group (Ponte et al. 2019).

This variation in the species reproduction is closely related to the environmental conditions that: favor the development of offspring, synchrony with the reproductive activity of adults and evolution results of strategies in the life history of the species (Smith \& Wootton 2016,
Zacardi \& Ponte 2016). Moreover, it corroborates the information that both in lentic and lotic water bodies, fish species present positive responses to environmental stimuli (Sanches et al. 2020).

Lake Juá has a history of disturbances arising from anthropogenic activities in its adjacent forest area that have modified the landscape and some of its limnological parameters. Among the

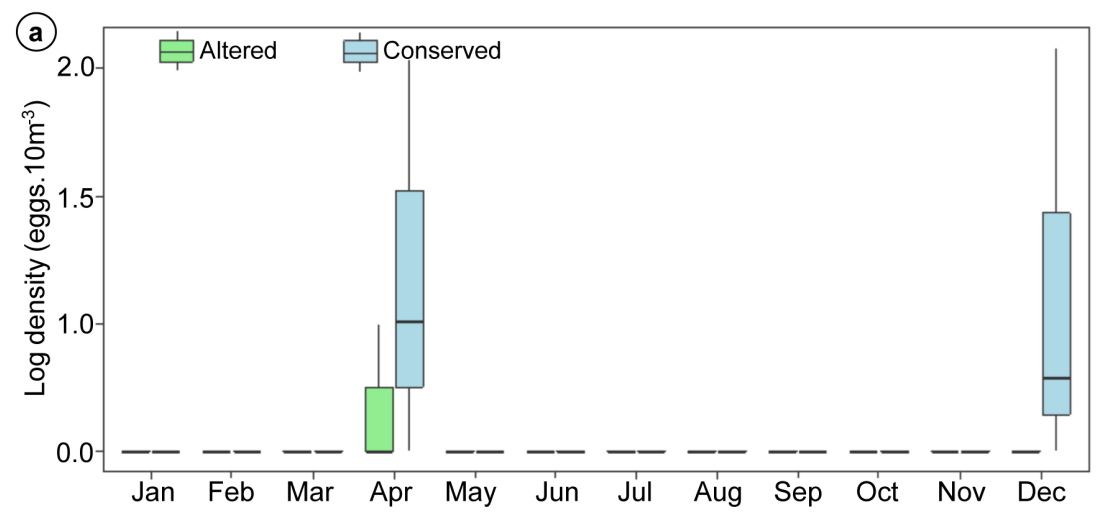

Figure 4. Variation in the density (log transformed) of a) eggs; b) fish larvae and c) species diversity between the altered and conserved areas of Lake Juá over the months of sampling, state of Pará, Brazil.
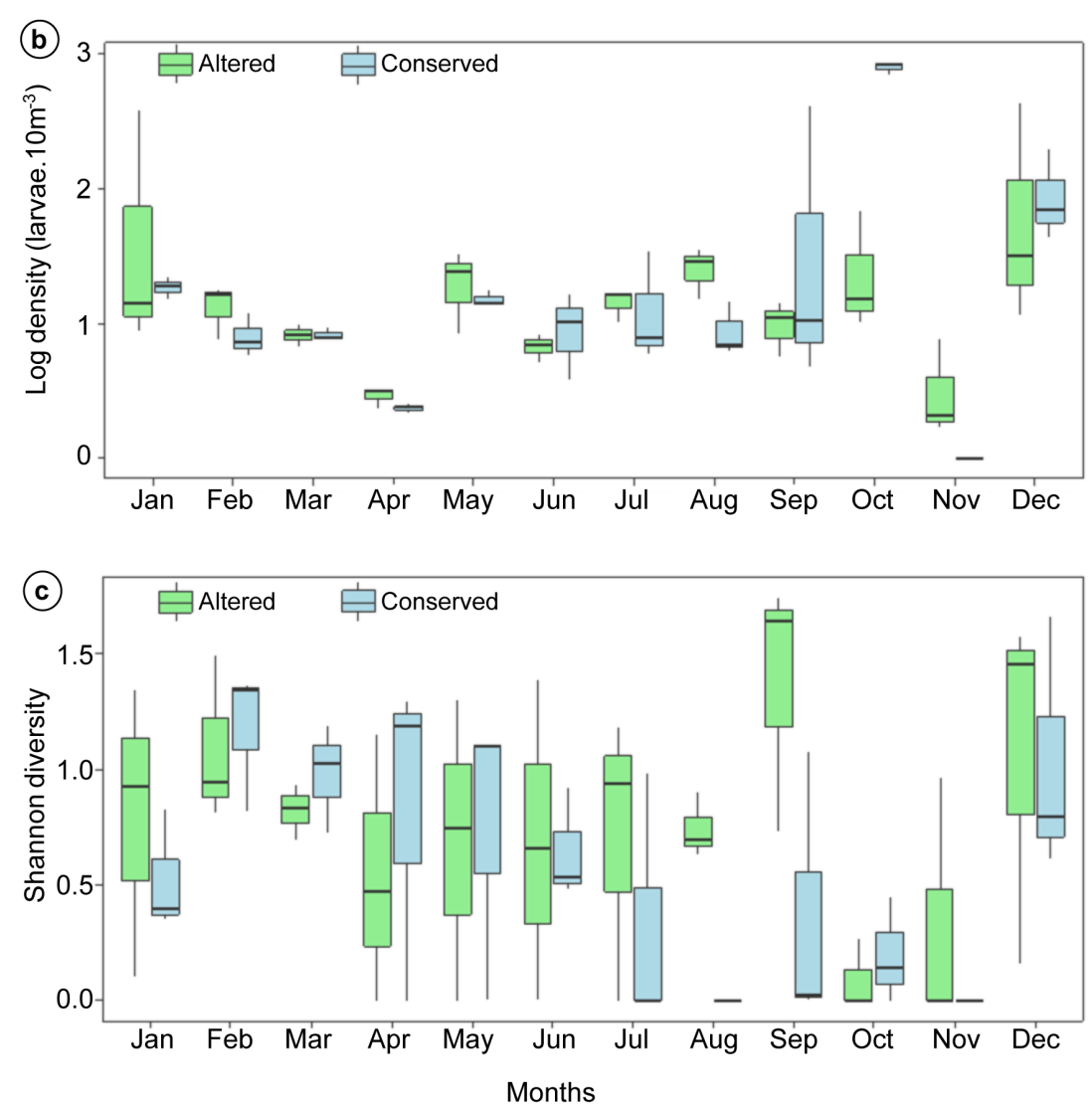
consequences of anthropogenic disturbances in the lake (i.e., deforestation of the area adjacent to the lake) are increased concentrations of inorganic matter, particulate matter, and high turbidity (Cardoso et al. 2021). The morphological and biogeochemical conditions of freshwater ecosystems are directly related to the presence of native vegetation in their surroundings and that deforestation has been one of the main causes of increased sediment exports to aquatic environments and soil erosion (Neill et al. 2001, Castello et al. 2013). Furthermore, changes in land cover, impacts of dam constructions and other degrading activities are reported as one of the responsible for the reduction of ecosystem services provided by aquatic environments (Castello \& Macedo 2016).

The temporal variation in the diversity of fish larvae was already expected, since the occurrence of certain species of the ichthyofauna is influenced by the complexity of the habitat and seasonality (Pinheiro et al. 2016, Oliveira et al. 2020a). The capture of eggs and fish larvae and the absence of significant differences in species diversity along the spatial scale in Lake Juá is an indication that this environment demonstrates a resilience capacity even with past environmental impacts having changed some lake conditions (Corrêa et al. 2018, Cardoso et al. 2021). This capacity may be related to the direct connectivity of the lake with the main river and the confluence of igarapés (streams), which allow greater flow in the exchange of water and ecological interactions of the species between the adjacent aquatic systems throughout all months of the year.

Since the lake has a direct connection with the main river (Tapajós River) and several streams, the presence of larvae within this environment can have three origins: coming from reproductive activities in the Tapajós River, resulting from the reproduction of small species in adjacent streams or from the gene flow that occurred within the lake itself. This allows us to infer that not only the lake is essential in the maintenance of the regional ichthyofauna,

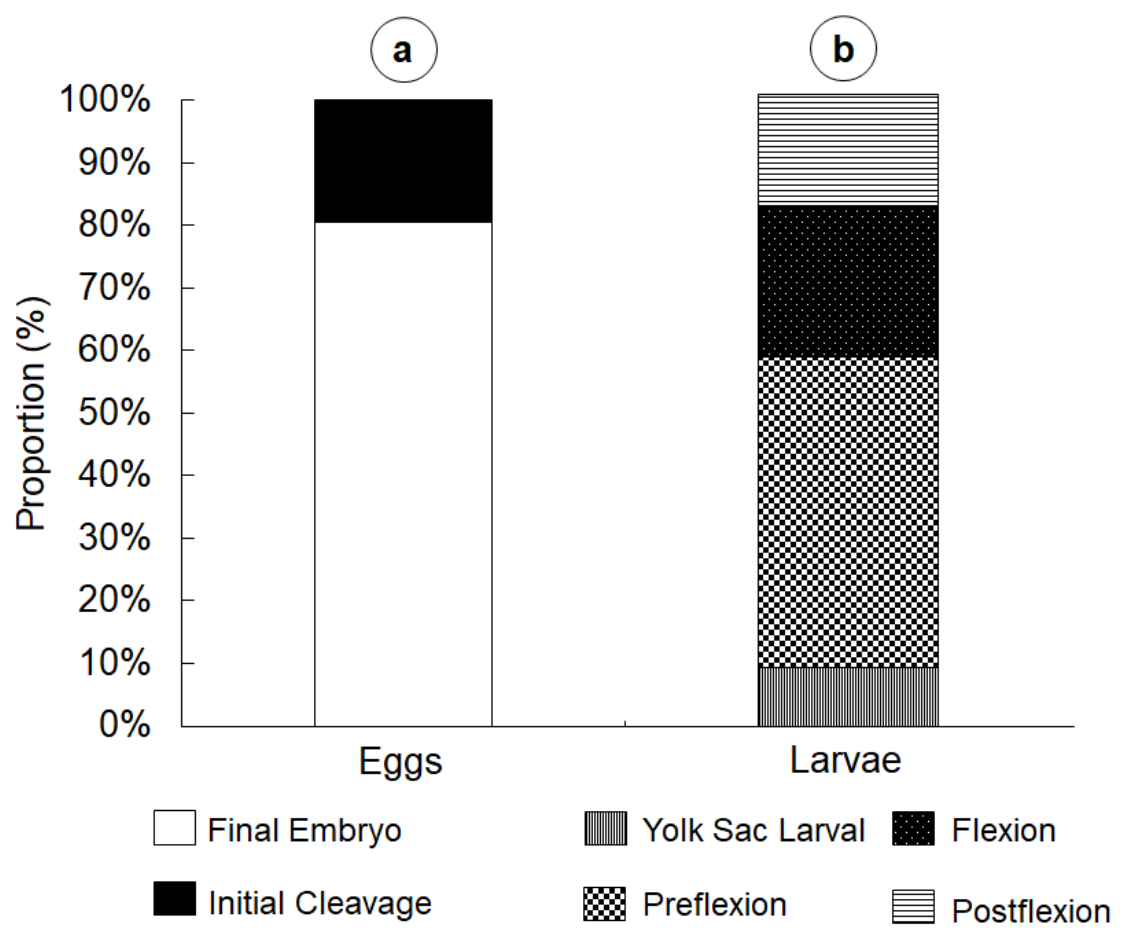

Figure 5. Variation of the capture proportion of development stages of a) fish eggs and b) larvae in Lake Juá, state of Pará, Brazil. 
but all the habitats that surround the lake environment, such as the streams, connecting channels and the main river are pivotal. In this sense, future studies should also focus on the role of these adjacent habitats in the occurrence and distribution of fish eggs and larvae.

The capture of eggs in the early and final development stages of non-migratory species emphasizes the premise of the use of this environment as a breeding site for resident fish species (i.e., which have their entire life cycle in the lake). The capture of larvae in early stages (yolk-sac and preflexion) and final development (flexion and postflexion) demonstrates that the lake helps in the renewal of the local ichthyofauna stocks and acts as nursery, growth and development area for the species.

Thus, maintaining the integrity and conservation of these environments that help the renewal of fishery stocks is essential because the improvement of environmental quality generates favorable conditions for the maintenance of fish communities, in addition to ensuring food security for local traditional populations (Pinaya et al. 2016, Begossi et al. 2019, Ponte et al. 2019, Zacardi et al. 2020b). After all, when ensuring the protection of habitats used during the early stages of fish life, the survival of offspring is maximized and the chances of success in the recruitment of populations are increased (Costa et al. 2016, Zacardi et al. 2017a).

In this case, it is essential to implement actions that minimize the environmental changes occurred in Lake Juá and that these measures are designed and implemented according to a participatory and shared management as an integrative tool among users (fishers, residents and tourists), environmentalists and public agencies. Consequently, the lake will continue to maintain its resilience, its ecological and socioeconomic importance. Furthermore, future studies should focus on the relationship of ichthyoplankton with the lake's environmental parameters and the influence of adjacent environments (streams and main river) on the input of eggs and fish larvae in the lake system. The results serve as a subsidy to public policies and to establish sustainable and efficient management actions with repercussions on regional fishing.

\section{Acknowledgments}

The authors would like to thank the collaborators of the Laboratório de Ecologia do Ictioplâncton e Pesca em Águas Interiores (LEIPAI) of the Universidade Federal do Oeste do Pará (UFOPA) for their assistance in the field. They also thank the Conselho Nacional de Desenvolvimento Cientifico e Tecnológico (CNPq) for the financial resources of this research.

\section{REFERENCES}

ANDERSON MJ. 2001. A new method for non-parametric multivariate analysis of variance. Austral Ecol 26(1): 3246. https://doi.org/10.1111/j.1442-9993.2001.01070.pp.x.

ARANTES CC, FITZGERALD DB, HOEINGHAUS DJ \& WINEMILLER KO. 2019. Impacts of hydroelectric dams on fishes and fisheries in tropical rivers through the lens of functional traits. Curr Opin Environ Sustain 37: 28-40. https://doi. org/10.1016/j.cosust.2019.04.009.

ARANTES CC, WINEMILLER KO, PETRERE M, CASTELLO L, HESS LL \& FREITAS CEC. 2018. Relationships between forest cover and fish diversity in the Amazon River floodplain. J Appl Ecol 55: 386-395. https://doi.org/10.1111/1365-2664.12967.

BARTHEM RB \& FABRÉ NN. 2004. Biologia e diversidade dos recursos pesqueiros das Amazônia. In: Ruffino ML (Ed), A pesca e os recursos pesqueiros na Amazônia brasileira. IBAMA/Provárzea, Manaus, p. 17-62.

BEGOSSI A, SALIVONCHYK SV, HALLWASS G, HANAZAKIC N, LOPES PFM, SILVANO RAM, DUMARESQ D \& PITTOCK J. 2019. Fish consumption on the Amazon: a review of biodiversity, hydropower and food security issues. Braz J Biol 79: 345357. https://doi.org/10.1590/1519-6984.186572.

BETANCUR-R R, WILEY EO, ARRATIA G, ACERO A, BAILLY N, MIYA M, LECOINTRE G \& ORTÍ G. 2017. Phylogenetic classification of bony fishes. BMC Evol Biol 17: 162. https://doi.org/10.1186/ s12862-017-0958-3. 
BLOOM DD \& EGAN JP. 2018. Systematics of Clupeiformes and testing for ecological limits on species richness in a trans-marine/freshwater clade. Neotrop ichthyol 16: e180095. https://doi.org/10.1590/1982-0224-20180095.

BLOOM DD \& LOVEJOY NR. 2017. On the origins of marinederived freshwater fishes in South America. J Biogeogr 44: 1927-1938. https://doi.org/10.1111/jbi.12954.

BRITO BC, FORSBERG BR, KASPER D, AMARAL JHF, VASCONCELOS MRR, SOUSA OP, CUNHA FAG \& BASTOS WR. 2017. The influence of inundation and lake morphometry on the dynamics of mercury in the water and plankton in an Amazon floodplain lake. Hydrobiologia 790: 35-48. https://doi. org/10.1007/s10750-016-3017-y.

CAIRES RA. 2013. Microphilypnus tapajosensis, a new species of eleotridid from the Tapajós basin, Brazil (Gobioidei: Eleotrididae). Ichthyol Explor Freshw 24: 155-160.

CAJADO RA, OLIVEIRA LS, SILVA FKS \& ZACARDI DM. 2020a. Ontogenetic structure and distribution patterns of ichthyoplankton in the confluence zone of two river systems in the Eastern Amazon. J Appl Ichthyol 36: 801810. https://doi.org/10.1111/jai.14111.

CAJADO RA, OLIVEIRA LS, SUZUKI MAL \& ZACARDI DM. 2020b. Spatial diversity of ichthyoplankton in the lower stretch of the Amazon River, Pará, Brazil. Acta Ichthyol Piscat 50: 127-137. https://doi.org/0.3750/AIEP/02786.

CARDOSO MC, ALVES HS, COSTA ICNP \& VIEIRA TA. 2021. Anthropogenic actions and socioenvironmental changes in lake of Juá, Brazilian Amazonia. Sustainability 13: 9134. https://doi.org/10.3390/su13169134.

CASTELLO L \& MACEDO MN. 2016. Large-scale degradation of Amazonian freshwater ecosystems. Glob Change Biol 22: 990-1007. https://doi.org/10.1111/gcb.13173.

CASTELLO L, MCGRATH DG, HESS LL, COE MT, LEFEBVRE PA, PETRY P, MACEDO MN, RENÓ VF \& ARANTES CC. 2013. The vulnerability of Amazon freshwater ecosystems: Vulnerability of Amazon freshwater ecosystems. Conserv Lett 6: 217-229. https://doi.org/10.1111/conl.12008.

CHAVES CS, OLIVEIRA LS, CAJADO RA, PONTE SCS \& ZACARDI DM. 2019. Distribuição espaço-temporal de larvas de Sciaenidae (Pisce, Acanthuriformes) no trecho inferior do rio Amazonas, Amazônia Oriental, Pará. Oecol Aust 23: 451-463. https://doi.org/10.4257/oeco.2019.2303.05.

CLARKE KR. 1993. Non-parametric multivariate analyses of changes in community structure. Austral Ecol 18: 117-143. https://doi.org/10.1111/j.1442-9993.1993.tb00438.x.

CORRÊA JMS, ROCHA MDS, SANTOS AA, SERRÃO EM \& ZACARDI DM. 2018. Caracterização da pesca artesanal no Lago Juá,
Santarém, Pará. Rev Agrogeoamb 10: 61-74. https://doi. org/10.18406/2316-1817v10n220181116.

COSTA ACL, JUNIOR JAS, CUNHA AC, FEITOSA JRP, PORTELA BTT, SILVA GGC \& COSTA RF. 2013. Índices de conforto térmico e suas variações sazonais em cidades de diferentes dimensões na região amazônica. Rev Bras Geogr Fis 6: 478-487.

COSTA MDP, POSSINGHAM HP \& MUELBERT JH. 2016. Incorporating early life stages of fishes into estuarine spatial conservation planning: Ichthyoplankton and Estuarine Spatial Conservation. Aquatic Conserv: Mar Freshw Ecosyst 26: 1013-1030. https://doi.org/10.1002/ aqc.2584.

DAGOSTA FCP \& PINNA MD. 2019. The Fishes of the Amazon: Distribution and Biogeographical Patterns, with a Comprehensive List of Species. Bull Am Mus Nat Hist 1: 1-163. https://doi.org/10.1206/0003-0090.431.1.1.

EGAN JP, BLOOM DD, KUO CH, HAMMER MP, TONGNUNUI P, IGLÉSIAS S, SHEAVES M, GRUDOAN C \& SIMON AM. 2018. Phylogenetic analysis of trophic niche evolution reveals a latitudinal herbivory gradient in Clupeoidei (herrings, anchovies, and allies). Mol Phylogenetics Evol 124: 151161. https://doi.org/10.1016/j.ympev.2018.03.011.

GARCIA DAZ, COSTA ADA, ALMEIDA FS, BIALETZKI A \& ORSI ML. 2018. Spatial distribution and habitat use by early fish stages in a dammed river basin, Southern Brazil. Rev Biol Trop 66: 605-621. https://doi.org/10.15517/rbt.v66i2.33384.

GOULDING M, VENTICINQUE E, RIBEIRO MLB, BARTHEM RB, LEITE RG, FORSBERG B, PETRY P, SILVA-JUNIOR, UL, FERRAZ PS \& CAÑAS C. 2019. Ecosystem-based management of Amazon fisheries and wetlands. Fish Fish 20: 138-158. https://doi. org/10.1111/faf.12328.

GRANADO-LORENCIO C, LIMA CRMA \& LOBÓN-CERVIÁ J. 2005. Abundance - distribution relationships in fish assembly of the Amazonas floodplain lakes. Ecography 28: 515-520. https://doi.org/10.1111/j.0906-7590.2005.04176.x.

JUNK WJ, PIEDADE MTF, SCHÖNGART J \& WITTMANN F. 2012. A classification of major natural habitats of Amazonian white-water river floodplains (várzeas). Wetlands Ecol Manage 20: 461-475. https://doi.org/10.1007/ s11273-012-9268-0.

LEAL C ET AL. 2018. Is environmental legislation conserving tropical stream faunas? A large-scale assessment of local, riparian and catchment-scale influences on Amazonian fish. J Appl Ecol 55: 1312-1326. https://doi. org/10.1111/1365-2664.13028.

LIMA AC \& ARAUJO-LIMA CARM. 2004. The distributions of larval and juvenile fishes in Amazonian rivers of different 
nutrient status. Freshwater Biol 49: 787-800. https://doi. org/10.1111/j.1365-2427.2004.01228.x.

LOPES CA \& ZANIBONI-FILHO E. 2019. Mosaic environments shape the distribution of Neotropical freshwater ichthyoplankton. Ecol Freshw Fish 28: 544-553. https:// doi.org/10.1111/eff.12473.

MAGURRAN AE. 2013. Measuring Biological Diversity. New York, Wiley-Blackwell, 266 p.

MELACK JM, NOVO EMLM, FORSBERG BR, PIEDADE MTF \& MAURICE L. 2009. Floodplain ecosystem processes. In: Keller M, Bustamante M, Gash J \& Dias PS (Eds). Amazonia and global change. Washington, AGU, p. 525-541.

NAKATANI K, AGOSTINHO AA, BAUMGARTNER G, BIALETZKI A, SANCHES PV, MAKRAKIS MC \& PAVANELLI CS. 2001. OVOS e larvas de peixes de água doce: desenvolvimento e manual de identificação. Maringá, Eduem, 389 p.

NASCIMENTO GO \& SANTOS JBA. 2019. Crise urbana e aglomerados subnormais: um olhar para a Vista Alegre do Juá. In: Reis ABO, Pinho ERP, Alves LNS \& Rodrigues YS (Eds). Cidades e bem viver na Amazônia. Santarém, Universidade Federal do Oeste do Pará, p. 171-182.

NEILLC, DEEGAN LA, THOMASSM \& CERRI CC. 2001. Deforestation for pasture alters nitrogen and phosphorus in small Amazonian streams. Ecol Appl 11: 1817-1828. https://doi. org/10.1890/1051-0761(2001)011[1817:DFPANA]2.0.CO;2.

NYNATTEN AV, BLOOM D, CHANG BSW \& LOVEJOY NR. 2015. Out of the blue: adaptive visual pigment evolution accompanies Amazon invasion. Biol Lett 11: 20150349. https://doi.org/10.1098/rsbl.2015.0349.

OBERDORFF T ET AL. 2019. Unexpected fish diversity gradients in the Amazon basin. Sci Adv 5: eaav8681. https://doi.org/10.1126/sciadv.aav8681.

OKSANEN J ET AL. 2019. Vegan: community ecology package. R version 2.5-6. https://CRAN.R-project.org/ package=vegan.

OLIVEIRA CC, SUZUKI MAL, OLIVEIRA LS \& ZACARDI DM. 2020b. Description of the initial development and temporal distribution of Microphilypnus tapajosensis larvae and juveniles in a reservoir in the Eastern Amazon. Cienc Nat 42: e49. https://doi.org/10.5902/2179460X41542.

OLIVEIRA LS, CAJADO RA, SANTOS LRB, SUZUKI MAL \& ZACARDI DM. 2020a. Bancos de macrófitas aquáticas como locais de desenvolvimento das fases iniciais de peixes em várzea do Baixo Amazonas. Oecol Aust 24: 644-660. https://doi.org/10.4257/oeco.2020.2403.09.
ORSI ML. 2010. Estratégias reprodutivas de peixes da região Baixa-Média do rio Paranapanema, reservatório de Capivara. São Paulo, Edgar Blucher Ltda, 116 p.

ORSI ML, ALMEIDA FS, SWARÇA AC, CLARO-GARCÍA A, VIANNA NC, GARCI DAZ \& BIALETZKI A. 2016. Ovos, larvas e juvenis dos peixes da bacia do rio Paranapanema: uma avaliação para conservação. Assis, Triunfal Gráfica \& Editora, 136 p.

ORTEGA JCG, DIAS RM, PETRY AC, OLIVEIRA EF \& AGOSTINHO AA. 2015. Spatio-temporal organization patterns in the fish assemblages of a Neotropical floodplain. Hydrobiologia 745: 31-41. https://doi.org/10.1007/s10750-014-2089-9.

OSORIO D, TERBORGH J, ALVAREZ A, ORTEGA H, QUISPE R, CHIPOLLINI V \& DAVENPORT LC. 2011. Lateral migration of fish between an oxbow lake and an Amazonian headwater river: Lateral migration in the Amazon headwaters. Ecol Freshw Fish 20: 619-627. https://doi. org/10.1111/j.1600-0633.2011.00511.x.

PINAYA WHD, LOBON-CERVIA FJ, PITA P, SOUZA RB, FREIRE J \& ISAAC VJ. 2016. Multispecies Fisheries in the Lower Amazon River and Its Relationship with the Regional and Global Climate Variability. PLoS ONE 11: e0157050. https://doi. org/10.1371/journal.pone.0157050.

PINHEIRO DT, CORRÊA JMS, CHAVES CS, CAMPOS DPF, PONTE SCS \& ZACARDI DM. 2016. Diversidade e distribuição da ictiofauna associada a bancos de macrófitas aquáticas de um lago de inundação amazônico, estado do Pará, Brasil. ActaFish 4(2): 59-70. https://doi.org/10.2312/ Actafish.2016.4.2.59-70.

PONTE SCS, OLIVEIRA LS \& ZACARDI DM. 2019. Temporal variation of fish larvae from a flooding lake as grant to environmental management. Jahec 1: 1-13.

PONTE SCS, SILVA AJS \& ZACARDI DM. 2017. Dispersion and nursery areas for Curimatidae (Pisces, Characiformes) larvae in low section of the Amazonas River, Brazil. Interciencia 42: 727-732.

RABELOYGS, VAZEM \&ZACARDIDM. 2017. Perfil socioeconômico dos pescadores artesanais de dois lagos periurbanos de Santarém, estado do Pará. Rev Desaf 4: 73-82. https:// doi.org/10.20873/uft.2359-3652.2017v4n3p73.

REIS RE, ALBERT JS, DARIO FD, MINCARONE MM, PETRY P \& ROCHA LA. 2016. Fish biodiversity and conservation in South America: fish biodiversity and conservation. J Fish Biol 89: 12-47. https://doi.org/10.1111/jfb.13016.

SANCHES PV, GOGOLA TM, SILVA RO, TOPAN DA, PICAPEDRA PHS \& PIANA PA. 2020. Arms as areas for larval development of migratory fish species in a Neotropical reservoir and the influence of rainfall over abundances. J Fish Biol 97: 1306-1316. https://doi.org/10.1111/jfb.14474. 
SERRÃO EM, BRAGA TMP, COELHO YKS, CAMPOS DPF, SANTOS AA \& ZACARDI DM. 2019. Conhecimento tradicional dos pescadores sobre o comportamento reprodutivo dos peixes em um lago de inundação no Oeste do Pará, Brasil. Soc Nat 3: 1-21. https://doi.org/10.14393/ SN-v31-2019-45133.

SILVA PA, REYNALTE-TATAJE DA \& ZANIBONI-FILHO E. 2012. Identification of fish nursery areas in a free tributary of an impoundment region, upper Uruguay River, Brazil. Neotrop ichthyol 10: 425-438. https://doi.org/10.1590/ S1679-62252012005000012.

SMITH C \& WOOTTON RJ. 2016. The remarkable reproductive diversity of teleost fishes. Fish Fish 17: 1208-1215. https:// doi.org/10.1111/faf.12116.

ZACARDI DM, BITTENCOURT SCS, NAKAYAMA L \& QUEIROZ HL. 2017a. Distribution of economically important fish larvae (Characiformes, Prochilodontidae) in the Central Amazonia, Brazil. Fish Manag Ecol 24: 283-291. https://doi. org/10.1111/fme.12222.

ZACARDI DM, BITTENCOURT SCS \& QUEIROZ HL. $2020 \mathrm{a}$. Recruitment of migratory Characiforms in the different wetland habitats of Central Amazonia: Subsidies for sustainable fisheries management. J Appl Ichthyol 36: 431-438. https://doi.org/10.1111/jai.14040.

ZACARDI DM \& PONTE SCS. 2016. Padrões de distribuição e ocorrência do ictioplâncton no médio rio Xingu, Bacia Amazônica, Brasil. Rev Agro Amb 9: 949-972. https://doi. org/10.17765/2176-9168.2016v9n4p949-972.

ZACARDI DM, PONTE SCS, FERREIRA LC, LIMA MAS, SILVA AJS \& CHAVES CS. 2017b. Diversity and spatio-temporal distribution of the ichthyoplankton in the lower Amazon River, Brazil. Biota Amazonia 7: 12-20. https://dx.doi. org/10.18561/2179-5746/ biotaamazonia.v7n2p12-20.

ZACARDI DM, SANTOS JA, OLIVEIRA LS, CAJADO RA \& POMPEU PS. 2020b. Ichthyoplankton studies as referential for the management and monitoring of fishery resources in the Brazilian Amazon basin. Acta Limnol Bras 32: e203. https://doi.org/10.1590/s2179-975x6619.

\section{How to cite}

DE OLIVEIRA LS, CAJADO RA, DOS SANTOS LRB \& ZACARDI DM. 2022. Structure of the ichthyoplankton community in a Neotropical floodplain lake affected by environmental degradation. An Acad Bras Cienc 94: e20201598. DOI 10.1590/0001-3765202220201598.
Manuscript received on October 5, 2020;

accepted for publication on April 21, 2021

\section{LUCAS S. DE OLIVEIRA ${ }^{1}$}

https://orcid.org/0000-0002-1631-0498

RUINERIS A. CAJADO $0^{1,3}$

https://orcid.org/0000-0002-7047-0302

\section{LUAN R.B. DOS SANTOS 1}

https://orcid.org/0000-0002-1679-8286

\section{DIEGO M. ZACARDI ${ }^{1,2}$}

https://orcid.org/0000-0002-2652-9477

${ }^{1}$ Universidade Federal do Oeste do Pará (UFOPA), Laboratório de Ecologia do Ictioplâncton e Pesca em Águas Interiores (LEIPAI), Rua Vera Paz, s/n, Bloco 11, Sala 4, Salé, 68035-110 Santarém, PA, Brazil

${ }^{2}$ Programa de Pós-Graduação em Biodiversidade e Conservação (PPGBC), Universidade Federal do Pará (UFPA), Campus Altamira, Rua Coronel José Porfírio, 2515, São Sebastião, 68372-040 Altamira, PA, Brazil

${ }^{3}$ Programa de Pós-Graduação em Ecologia Aquática e Pesca (PPGEAP), Universidade Federal do Pará (UFPA), Cidade Universitária Prof. José Silveira Netto, Av. Augusto Corrêa, 1, Guamá, 66075-110 Belém, PA, Brazil

Correspondence to: Lucas Silva de Oliveira

E-mail: lucasmdcpa@gmail.com

\section{Author contributions}

DMZ, LRBS, LSO and RAC were responsible for the sample design, collections, counting and identification of the ichthyoplankton. LSO and RAC produced the statistical analysis. LSO produced the results and discussion. DMZ reviewed all text of the manuscript.

\section{(cc) BY}

